\title{
The Imperative of Male Inclusion: How Institutional Context Influences the Policy
}

Kate Bedford

International Feminist Journal of Politics, 9 (3) pp289 - 311

\section{Not Published Version}

\begin{abstract}
This paper examines the role of institutional context in shaping policy agendas through a case study of the World's Bank's gender lending in Ecuador. Using interviews with employees and analysis of policy texts I explore the complex institutional location of Bank gender policymakers, identifying two key constraints on their policy output: 1. the pressure to frame gender policy using appeals to productivity and efficiency, and 2. the pressure to frame gender policy as producing complementary sharing between men and women. Given that the efficiency constraint has been much debated in feminist Bank scholarship I explicate the complementarity constraint in more detail. Specifically, I argue that the institutional pressure to define gender policy through a complementary focus on couples led poor men to become hyper-visible as irresponsible partners, and as the crux of the gender policy problem. In turn Bank gender policy was focused on efforts to change them, by encouraging their loving attachment to family and willingness to do domestic labor. I see cause for concern at the dominance of these policy solutions, and I consider how to facilitate their contestation in closing.
\end{abstract}

Keywords: World Bank, gender and development, Ecuador, masculinity, sexuality.

\section{Introduction}

Feminists grappling with development have long debated the dilemmas of gender work inside mainstream institutions. Drawing on the scholarship of institutionalists and policy analysts, ${ }^{\mathrm{i}}$ development specialists have examined how best to promote feminist agendas within non-feminist organizations, and in so doing they have highlighted similar themes regarding the persistence of bureaucratic hostility to gender interventions, and the dangers of cooptation. ${ }^{\text {ii }}$ These debates have assumed added import in recent years with the shift to gender mainstreaming in development lending. Mainstreaming requires that gender concerns become "an integral dimension of the design, implementation, monitoring and evaluation of policies and programs in all political, economic and societal spheres" (UN 
ESOSOC 1997). This will, theoretically, take gender to the heart of development. Thus scholars and practitioners are increasingly focusing on how gender can be made to fit within existing organizational mandates, and how such mandates may constrain feminist policy output. ${ }^{\text {iii }}$

In an attempt to contribute to this debate I explore the role of institutional context in shaping World Bank gender efforts. I seek to explain how gender policy gets made in the world's largest and most influential development institution, drawing attention to a currently under-theorized constraint within which policymakers operate - the imperative to include men in order to encourage complementary partnerships between couples. I outline this imperative alongside the far better-known requirement that gender interventions improve efficiency, before tracing some of its troubling consequences using a case study of Bank activities in Ecuador. I explore in closing how these findings relate to broader debates about feminist interventions in the Bank's contemporary gender policies.

\section{The World Bank: Institutional Development in Conditions of Mission Flux.}

Anyone seeking to understand contemporary development policy must understand the Bank. ${ }^{\text {iv }}$ It employs nearly 10,000 people and approved US\$22.3 billion in loans and grants in FY2005 (World Bank 2006) - more money than any other development body. Bank staff are also regarded by many as the development experts, as guarding “development's brain trust" (Birdsall and Kapur 2005: 4; Mallaby 2004; Pincus and Winters 2002). ${ }^{\mathrm{V}}$ This primacy within the field has made the Bank a prominent target of criticism by those who believe it has the wrong answers to development problems ${ }^{\mathrm{vi}}$, and it also creates an imperative to understand why the organization generates certain solutions to pressing policy questions rather than others. 
In addressing this issue Bank scholars have focused considerable attention on the institution's oft-shifting mission, with many arguing that it is increasingly torn between competing identities (Mallaby 2004; Gilbert and Vines 2000, Fox and Brown 1998). During the 1980s the Bank was a key advocate of the neo-liberal Washington Consensus, aiming to cut back the state, open trade, reduce social spending, deregulate, and privatize. This approach led to considerable protest from civil society organizations, in turn stimulating a "limited, but significant ideological shift" (O'Brien et al. 2000: 9) within the Bank involving increased skepticism about the market. In particular the institution was transformed after the 1995 appointment of James Wolfensohn as President, heralded as "the renaissance banker" in an online Bank biography. ${ }^{\text {vii }}$ Wolfensohn met with Bank critics, he collaborated with NGOs, and he spoke of holistic development frameworks that recentered poverty concerns. He left in May 2005, his reform agenda partially accomplished, ${ }^{\text {viii }}$ to be replaced by Paul Wolfowitz - a neo-conservative architect of the war on Iraq and a man of whom many Bank staff disapproved. ${ }^{\text {ix }}$ However Wolfowitz has so far made few drastic changes; a recent overview notes that many employees are still "waiting for the Stealth bomber to strike"” (Calderisi 2006: 24). The Bank's mission thus remains in flux, torn between adherence to neo-liberal imperatives and social development concerns. Its answers to key policy questions - including the ones related to women/gender - are embedded in this context.

Gender Policy and the Bank: Shifting Institutional Constraints and the Emergence of the Complementarity Rationale.

The Bank started paying attention to the inequitable effects of its development policies on women, and the need to incorporate gender concerns into lending, in the mid 1970s (Murphy 1995; World Bank 2001; Moser Törnqvist and van Bronkhorst 1999). 
However the institution's crisis in mission and its embrace of social development concerns opened particularly conducive space for gender advocates. Gender issues within the Bank became increasingly visible after 1995, with Wolfensohn regarded as "a tremendous positive resource for change" by gender staff (O'Brien et al. 2000: 53). He led the Bank's delegation to the UN's Fourth Conference on Women, for example, and between 1995 and 2001 the proportion of projects that included some consideration of gender issues in their design almost doubled, to nearly 40\% (Long 2003: 7). By 2001 the Bank was positioning itself as the disseminator of "good practice" on gender in the development community (World Bank 2001: 273).

Scholars who have studied this effort to incorporate gender concerns into the Bank draw attention to two particularly important factors: 1 . the liminal "insider/outsider" space inhabited by feminist bureaucrats, and 2. the importance of efficiency arguments. Gender efforts have been heavily reliant on motivated staff (or their wives) ${ }^{\mathrm{x}}$ who pressure the institution from inside. Although maintaining strong external connections with Bank critics, ${ }^{\mathrm{xi}}$ they have largely pursed a policy of "entryism" to achieve their goals in which they attempt transformation from within by showing how women's advancement can serve existing institutional agendas (Miller and Razavi 1998: 2). The Bank's charter forbids it from engaging in activities that do not have economic development as their objective, and furthermore the institution's internal culture is professional, technocratic, economistic, and statistics-driven (O'Brien at al 2000: 47). This context results in well-known pressures for efficiency framings of gender policy, focused on how attentiveness to gender enhances productivity and growth. Indeed Bank staff are notorious in development circles for "stressing the business case for gender equity" $(45)^{\mathrm{xii}}$ - in recent years they have researched the economic effects of rape, domestic violence, illegal abortion, and HIV/AIDS; the 
returns from investment in women's health and education (World Bank 2000a: 5); and the bargaining disparities manifest in dowry murder (Bloch and Rao 2000).

These rationales for gender policy are the subject of fierce debate. Some observers note their strategic value in granting space for gender advocacy within institutional constraints (e.g. Staudt 2002; Rathgeber 1995). Others point to the poor data on which many efficiency-based claims are made, ${ }^{\text {xii }}$ or are concerned that they render feminist development efforts complicit in neo-liberal restructuring (Kuiper and Barker 2006; Wood 2003). Several specialists interviewed for a recent overview of gender issues in the Bank criticized the emphasis on economic efficiency over empowerment or rights and the subsequent promotion of gender equality within the prevailing economic reform paradigm, for example (Long 2003). These debates remain unresolved; I mention them simply to demonstrate that those interested in the Bank's gender efforts know that efficiency constraints structure policy output, and we continue to debate the wisdom of playing by such rules given the negative consequences that may result.

To reiterate, however, the Bank has changed. Broadly, alternatives to efficiency became more visible with the re-emergence of a poverty focus under Wolfensohn, and discourses of empowerment, civil society, and rights are now central to published work. ${ }^{\text {xiv }}$ Anthropologists and sociologists have been targeted in an effort to expand qualitative research in the institution (Escobar 1997), and photographs are increasingly used alongside tables to demonstrate development truths - the 2006 World Development Report even has a Diego Rivera mural on its front cover (World Bank 2006). Moreover, the Bank's gender initiatives increasingly draw on non-efficiency justifications. I focus here on the growing importance of an argument I term the complementarity rationale for gender policy. This claims that gender interventions help to produce and reinforce sharing partnerships between men and women, and that they should subsequently be supported by the Bank as a 
development good. While the causes underpinning the emergence of this policy rationale are complex, ${ }^{\mathrm{xv}} \mathrm{I}$ briefly examine two factors in this section: the Bank's shift from Women in Development (WID) to Gender And Development (GAD); and the definition of couplehood as empowering.

Although elsewhere understood as involving Third World critique of the liberal feminist failure to contest neo-colonialism and capitalism (Sen and Grown 1985; Kabeer 1994), within the Bank GAD was seen as a planning intervention to help mainstream gender concerns throughout lending by adopting a relational approach that included men. By the early 1990s gender advocates perceived that their concerns had been marginalized, languishing in underfunded women-only projects and disconnected from the Bank's overarching development activities. It is well known that staff embraced efficiency rationales in part to increase their impact in this respect (Murphy 1995). However they also embraced the move from WID to GAD as defined in Caroline Moser's key planning text, wherein WID was seen as focusing on women in isolation while:

"the GAD approach maintains that to focus on women in isolation is to ignore the real problem, which remains their subordinate status to men... (I)t emphasizes a focus on gender relations, when designing measures to "help" women in the development process" (1993: 3).

Moser, a UK development academic who was subsequently employed by the Bank, intended GAD to generate transformative interventions that countered women's subordination (4), but through a relational lens that highlighted microsocial male-female interactions. A 1995 internal evaluation of Bank gender lending noted that Moser's approach was preferred others precisely because "more emphasis is put on the relational aspect of gender, the relations between men and women" (Murphy 1995: 108). Hence the Bank's first policy paper on gender differentiated WID from GAD on the following basis:

“The World Bank's early 'women in development' programs tended to treat women as a special target group of beneficiaries in projects and programs. The policy framework is now broadening to reflect the ways in which the relations between women and men 
constrain or advance efforts to boost growth and reduce poverty for all. This focus characterizes the 'gender and development' approach" (World Bank 1994: 12).

Not surprisingly this emphasis on men and relationality was also central to a 1999 evaluation co-written by Moser, intended to help "create a Bankwide consensus" on gender analysis (Moser Törnqvist and van Bronkhorst 1999: v). This report praised El Salvador's country gender strategy, which aimed to "creat(e) a more gender equitable division of labor in the household" (26), while criticizing projects and projects that ignored men (8). By this point male inclusion had become a defining feature of successful gender policy.

In addition, after 1995 the production and reinforcement of sharing partnerships between men and women was increasingly linked to empowerment within the Bank. The language of empowerment - "a chimera than lets everyone feel comfortable - a 'motherhood' term with a warm, cuddly feeling" (Parpart 2002: 52) - was used more frequently after Wolfensohn embraced social development concerns (Moser Törnqvist and van Bronkhorst 1999: 10). In relation to gender, the achievement of sharing partnership was framed as empowering and liberatory to both men and women. The notion was particularly evident in Wolfensohn's speech to the 1995 Beijing conference, in which he issued "a challenge for women - and men too" (Wolfensohn 1995: 2). This:

"will require not just the liberation of women, but also the liberation of men - in their thinking, attitudes, and willingness to take a fairer share of the responsibilities and workloads that women carry on their shoulders. To bring about real improvement in the quality of women's lives, men must change. And action must begin at home. For each of us, change lies in the kind of household we live in, the society we help to build, and the institutions we work for" (3).

Although both men and women are understood to benefit from such balanced sharing, Bank gender efforts involve a particular emphasis on what men can gain from more loving roles, urging them to "be given the opportunity to be part of the traditionally feminine sphere of being loving, considerate, participatory, listening, having patience, understanding, learning, caring" (World Bank 1995b: 6-7). Hence the Bank frames its role 
in GAD efforts as "helping in-country agents who are working to change gender relations" (World Bank 2000b: 5) in these directions. The perceived need to keep men in families is crucial here. Recent gender documents have advocated male involvement in population control efforts, changes in marriage law, and tax, pension, and social security reform aimed at increasing sharing in the family (World Bank 1995a; 1995c; 2001), while the Bank's regional gender website currently highlights a US\$6.72 million project on Family Strengthening and Social Capital Promotion in Argentina. ${ }^{\text {xvi }}$

To clarify, this overview is not intended as a comprehensive causal account of the complementarity rationale for gender policy. I seek simply to register that it is now a prominent discourse at the D.C. level, operating alongside efficiency rationales. This remains true after Wolfensohn's departure. In a recent Bank-hosted conference on the Millennium Development Goal of gender equity, Wolfowitz gave an opening speech containing a segment entitled "A Cart With Two Wheels," explained thusly:

"During my visit to Pakistan this past summer, one poor woman told me that development is like a cart with two wheels - one man and one woman. If one of the wheels isn't moving, the cart won't go very far" (Wolfowtiz 2006, n.p.).

The Bank's gender webpage illustrates this conference with a graphic of a set of scales balanced by a male and female figure on each side (www.worldbank.org/gender/) - a perfect visual representation of the complementarity rationale and its current centrality to the world's largest development institution. ${ }^{\text {xii }}$

\section{World Bank Gender Policy In Ecuador.}

How, then, does this policy framing filter down to influence activities on the ground? How do staff navigate these dual institutional constraints? And how can research into these topics help generate fruitful policy critique? Case studies are one - albeit incomplete - stage in answering these questions since they provide insight into policy and 
project operations. Seeking to explore Bank interventions in this way I examined gender activities as debated and enacted in Ecuador since Wolfensohn took over as President in 1995. I conducted interviews with GAD staff and consultants during visits in 2003 and 2004, and I analyzed relevant documents put out by the Bank's resident mission in Quito. I also conducted fieldwork on Bank gender lending at the policy and project level.

Ecuador is an interesting site for closer interrogation of Bank policy for several reasons. It is heavily indebted, it is in economic crisis, and it has been deeply divided by conflict over restructuring since the 1980s (Fretes-Cibils and López-Cálix 2003; North 2004; Whitten 2003). These conditions are hardly uncharacteristic of the contemporary Latin American development experience, and elsewhere I argue that Bank lending to Ecuador is broadly representative of its development approach throughout the region (Bedford 2005a).

More importantly, however, Ecuador is an excellent site for research into Bank gender policy. Bank gender efforts rely on strong, D.C.-located regional support units that work in partnership with country-level initiatives to produce research such as gender reviews of development issues, and to mainstream gender into projects and policies. The Latin American and Caribbean region is regarded as having the most advanced gender unit in the Bank (Hafner-Burton and Pollack 2002: 368; Long 2003: 9; Zuckerman and Qing 2003: 27). In turn the Bank's office in Ecuador put out one of the most comprehensive gender reviews of all countries in the region, mentioned in a recent D.C. Bank report (World Bank 2000a: 27). Moreover, the Bank's resident mission in Quito has been an important site for domestic and regional gender policy entrepreneurship. It was the site for a regional Bank conference on gender in 2000, for example, and several Ecuadorian gender consultants were hired to work with PROGENIAL, an initiative established by regional staff in 2000 to study the impact of gender in Bank activities (Long 2003: 9; Törnqvist 
2004). National gender specialists have also been involved in the Bank's country initiatives on ethnodevelopment, justice, and rural development. These individuals have close links to the Ecuadorian feminist movement, funding national events for women's day, for example, and collaborating with academic institutions, the state's women council (CONAMU), and Afro-Ecuadorian and indigenous women's groups. ${ }^{\text {xviii }}$

Finally, the Bank has put out several important documents on gender in Ecuador, including many written by Caroline Moser. In addition to publishing extensively on GAD issues both inside and outside the Bank (1993; 1996; 1997; Moser, Törnqvist and von Bronkhorst 1999; World Bank 1996), Moser is well-known for a pioneering study in the 1980s on gender and poverty in Cisne Dos, a low-income housing settlement in Guayaquil (Ecuador's largest city). This was extended into a larger project on household vulnerability to economic change, funded and published by the Bank as Confronting Crisis. More recently, the Bank funded a study on gender and time use focused on the Ecuadorian flower industry (Newman 2001), used to inform both the Ecuador Gender Review and the Bank's most important D.C. policy text on gender to date, Engendering Development. In short, then, the case study allows a close look at what happens when gender staff gain space and at the constraints within which they are forced to operate, even in relatively friendly environments.

\section{Predictably, Insider/Outsiders Navigate The Horrible Frustrations of the Efficiency Constraint.}

Unsurprisingly, this exploration confirmed that the gender policy entrepreneurs working for the Bank in Ecuador occupy liminal spaces, as dual insiders and outsiders, and that their activities are heavily influenced by efficiency constraints. When interacting with other staff in the Ecuador office one gender employee commented "some people saw us a 
little as foreigners, as strange." Such a designation was not entirely inaccurate. These were largely James Wolfensohn's people, his cadre of progressive, non-economist recruits who felt in part accountable to "outsiders" in the feminist and development community. They were not necessarily supportive of the Bank's macroeconomic restructuring program, and they all wished to open the organization's operations up to greater civil society participation. For example staff were very proud of their translation of the Ecuador Gender Review into Spanish, and the launch of a Quichwa-language webpage on the Bank's Ecuador site.

That said, however, as much as they felt distanced from the Bank's macroeconomic reforms, and as much as they could rely on support from the regional gender unit, without exception these policymakers claimed that their activities were heavily restricted by the dominance of the neo-liberal paradigm in the Bank, in the form of the efficiency constraint. As one employee noted, "its not that you can do everything, right? Because the Bank is very rigid." As another framed it, "the World Bank has an absolutely technocratic vision of gender." Staff were offered advice on how to navigate this rigidity through workshops on social marketing, to explain how "to sell" their findings to projects. This resulted in predictable pressure to produce economistic, quantifiable results. Thus one consultant argued that the regional gender unit, through PROGENIAL, was trying "to convince people that gender can work, that it is not only a question of propaganda, that it is not only a banner, but that if inequities can be measured they can be accepted...As you see, it is a quite positivistic field." Hence one of PROGENIAL's most lauded successes was the gender disaggregated data collected as part of Ecuador's agricultural census loan. Likewise in a discussion of "lessons learnt" from an attempt to integrate gender concerns into a rural development loan, the Ecuador Gender Review recommended a shift from a feminist, ideological orientation to a technocratic one grounded in efficiency (Correia 2000: 80). The 
state women's council, CONAMU, was praised by the Bank precisely because it valued quantifiable research and "technical excellence" in this way (8).

Sometimes these institutional pressures for efficiency led to anger at those who were understood to jeopardize the tentative space secured for feminist influence by producing poor quality work that could not be defended to the macroeconomists. On other occasions, the Bank's demand for efficiency-based justifications caused conflicts between national and D.C. priorities, and led policymakers to feel ashamed of their accomplishments when they were reduced to terms the Bank considered legible. One consultant said that the Bank arrived with "its little drawer of obvious approaches," an approach that caused conflict "because what were achievements for us, for them were worthless." When staff tried to present such achievements at a workshop, they saw their efforts converted into "a worthless formula...It embarrassed us that our achievements were presented in this manner." To sum up this issue s/he relayed a conversation with a person "with good intentions" from the Washington team:

“"you have good things,' s/he told us, 'yes, you have good things, but they are not well packaged, do you understand?' It was terrible...I didn't know how to do the packaging. It was horrible, horrible I swear to you - the biggest frustration."

Such findings confirm the continued salience of efficiency constraints in a post-1995 context.

\section{The Complementarity Constraint}

However there was also a second policy constraint evident in the Bank's Ecuadorian gender efforts. Staff also identified the pressure to include men, and to redefine gender in a complementary way, as a key limitation on their work. According to one interviewee gender was seen by some in the institution and in the projects with which PROGENIAL was trying to work as an external imposition, and as synonymous with 
feminist and/or "almost lesbian."xix In part to counter such perceptions, several employees said that the Bank wanted men included in gender work. As defined by one consultant, the official policy was: “we don't believe that there should be projects for women and projects for men; there should be projects with a focus on equity for men and women." Likewise, in policy texts attention to men and organizing in mixed groups were identified as key elements distinguishing an "ideological women in development approach over a true gender perspective" (Correia 2000: 76). The Ecuador Gender Review hence recommended male inclusion and the organizing of men's groups as one of the "lessons learnt" from a rural development loan (80), while the chapter on gender in the Bank's report on Ecuador's dollarization lamented that literature on gender and macroeconomic crisis "focuses almost solely on women to the exclusion of men" (Correia 2002: 178). A 2002 mission involving the regional gender unit included discussion of "themes relevant to men in Bank-funded projects," confirming the issue's importance in current gender efforts.

\section{Consequences (1): “A Very Ugly" Conflict Between Consultants.}

This approach to gender analysis had several concrete consequences for Bank activities in Ecuador. Firstly, it caused serious conceptual problems, confusing staff and the projects with which they worked. One policymaker stated that PROGENIAL had been less than successful in part because it was hard to maintain the position that gender refers to men and women when "I was always focusing more on women... Really, it was a little of a clash." Moreover, pressure was put on Ecuador's state feminist agency, CONAMU, to include men. Consider this account from a former Bank consultant:

"initially this project (PROGENIAL) was going to have strong involvement from CONAMU, but there was a misunderstanding between (the people involved). The misunderstandings have to do basically with conceptual themes such as how to conceive gender...For CONAMU although they speak of gender, (they have) a strong focus on women. In contrast the World Bank, as you may have seen, makes an effort towards gender because gender takes into account the theme of men... CONAMU 
refused very firmly to work like this, that men would be beneficiaries of their activities, and their argument was this - "we women are those who suffer discrimination, so as a result it is absurd, unjustifiable to invest in men"... This provoked a very strong disagreement...The relationship turned very very bad, very bad, and this affected all types of personal relations. But it was very ugly, this polemic - very ugly."

This consultant clearly sympathized with CONAMU's position and felt that gender staff had been pressured into a complementary focus on men by the Bank, a move that significantly damaged relations between feminist colleagues. This suggests that Bank work with liberal feminist organizations concerned with discrimination can be dramatically unsettled by the institution's focus on sharing couples.

\section{Consequences (2): Poor Men Are Made Visible as Irresponsible Partners.}

In addition to confusing staff and causing conflict with domestic allies, the vision of ideal gender analysis used in the Bank - as including men, and as aiming at complementary relations within loving couples - also influenced how the gender policy problem was defined. Put simply, as one gender consultant joked:

"We're not working with women here, right? We're working more with men, because the problem is the men (laughing). The problem isn't the women, the problem is the men. You have to be working with them."

Specifically, men were framed as unreliable policy problems who failed to adhere to a complementary model of good partnership. These representations often stemmed from the attention to men's irresponsibility given by poor Ecuadorian women themselves. For example, Moser's gender chapter in the Bank's 1996 Ecuador Poverty Report - based on her Cisne Dos research - included several text boxes which highlighted personal stories of community members. These overwhelmingly featured women who had been deserted, abused, financially exploited, and/or mistreated by selfish men (World Bank 1996: 126127). One text box in a 1997 report on the community focused on a man who had to abandon his dental studies due to cost and whose family remained below the poverty line 
despite the fact that both he and his son had several jobs (Moser 1997: 44). However this was one of the only positive representations of poor men in the text boxes - a pattern that is repeated in more recent Bank texts (Correia 2002: 186).

More significant than this disproportionate focus on poor male irresponsibility, however, were the direct claims that poor men are particularly oppressive to women, and more lazy and violent than their better-off counterparts. Poor men's drinking was identified as a key policy problem in this regard. The issue was raised in several interviews, understood as involving poor, rural, depressed men who go into cities, drink their wages, and put women at risk of violence. Likewise Moser's report on Cisne Dos explored "the role of drinking as a form of male release from despondency associated with economic and job difficulties" (Moser 1997: 77). However concern with poor men's irresponsible drinking as a key cause of Ecuador's gender problems, and as a reaction to wounded masculinity, is more sustained in recent texts. For example the issue took up half of a four page section on health in the Ecuador Gender Review (Correia 2000: 17) - far more space than cancer, STDs, occupational health and hazardous work, or smoking.

Many of the Bank's recent texts also argue that gender role stress leads poor men, and particularly unemployed men, to be violent and to have reduced capacities for caring. For example increased male violence was proof of the gendered impact of economic restructuring for the Ecuador Gender Review, since "for men, unemployment threatens their role of family provider and creates problems of self esteem and depression - which may have other possible negative effects such as violence"(Correia 2000: 50). Although subsequently violence was linked to alcohol abuse, leading to suggestions that drunk men should be detained by the police as a violence prevention strategy, both violence and alcoholism were understood to be caused by wounded masculinity. Thus the report argued that: 
"Causes of male violence - including street violence and sexual and domestic aggression - have been linked to masculinity and gender roles. According to Barker (1998), to be a man in Latin America is equated with working hard, earning well, being responsible, and providing financially for the family. When these goals become difficult to achieve, men regularly assert their masculinity through violence (ibid.)." (22).

The Bank's chapter on gender in its recent dollarization report went even further in this negative portrayal of poor masculinity, mentioning not only violence but also stunted emotional development and destructive behavior which are "probably the result of socialization processes, which inhibit men from expressing their feelings" (Correia 2002: 201). Again poor men were particularly affected, since "aggression among men has been associated with male gender roles and expectations, and in particular the inability of men earning low incomes to live up to societal and familial expectations of being full income earners" (189). Unemployed men were thus again regarded as at risk "of alcoholism, violence, delinquency, or depression" if unable to fulfil their breadwinner role (188), while elsewhere the report asserted that increased violence correlates with low education and belonging to a low socioeconomic group (186).

These claims of poor men's irresponsibility and violence persist despite the availability of contradictory evidence. For example the citation to Barker 1998 in the above quotation is to a conference paper. Better known literature on Latin American masculinity, which questions pathologizing portrayals of poor men as hyper-violent or irresponsible is ignored (e.g. Gutman 2003; Melhaus and Stolen 1996). ${ }^{\mathrm{xx}}$ When contradictory evidence is cited in Bank texts, its implications are ignored. For example, claims about poor men's laziness persist despite the recognition by the Bank's macroeconomists that poor men in Ecuador start work earlier than non-poor men (World Bank 1996: 74); that poor boys drop out of school to work at faster rates than any other group (Correia 2000: 5); and that many regions of the country suffer from gender imbalances caused by poor men's migration for work (11). Similarly, one study on domestic violence in Ecuador, cited in the Ecuador 
Gender Review, found no significant relationship between socio-economic class and domestic violence, while another in Lima found "that employed men inflict more physical and psychological violence than unemployed men, most probably because men are more dependent on female earnings" (Correia 2000: 22). While all of these findings challenged the portrayal of poor men as disproportionately dangerous, none received elaboration.

To clarify, in discussing these concerns I seek neither to romanticize anyone's masculinity, nor to deny problems of irresponsibility, alcoholism, and violence. I seek simply to demonstrate how men are made visible in, and targeted for inclusion through, gender policy. Men are included in ways that address the pathologies identified above. Thus the Bank asserts that research on alcoholism, violence, and delinquency should be conducted to correct "information deficiencies on men" (Correia 2000: vii). This is in many respects a perfect example of Arturo Escobar's observation that the development gaze seeks to include new populations as objects of intervention, as problems to be resolved "but according to interests defined by others" (1995: 190). Poor men are hereby targeted to correct their perceived irresponsibility and their failure to adhere to a model of normative couplehood considered empowering by the Bank. This agenda, I am arguing, emerged in a complex interplay between the institutional pressure to include men and the institutional definition of gender lending as requiring complementarity. I hope there is space to trace that process without denying gender inequality, and while remaining generous to the efforts of marginalized gender staff acting within constrained contexts.

\section{Consequences 3: Encouraging Better Loving.}

Given that the Bank's gender efforts require male inclusion and rest on a celebratory approach to sharing couplehood, the solutions that stem from the above definition of the policy problem focus on keeping men around and making them more 
reliable partners, rather than on supporting women's individual self-sufficiency. Specifically, the Bank's gender specialists seek to teach poor Ecuadorian men how to be responsible family members, particularly in order that they can help pick up the slack of unmet care needs as their wives move into paid employment. Getting poor women into work and getting poor men into parenting classes are thus considered complementary strategies, persistently framed as mutually supportive and equally necessary priorities, and as empowering to both parties. Consider, for example, the priority areas mentioned by the Ecuador Gender Review:

"First, both female and male gender issues need to be considered..., so that, inter alia, programs strengthen the role of fathers and provide income generating opportunities for women" (Correia 2000: xii).

Specific suggested interventions included "programs to promote men as fathers" which although "still very new in the Region and elsewhere... could be piloted in Ecuador" (xi). For example the Gender Review mentioned the need for reproductive health programs "to develop services for men in line with their needs, and to promote more active male participation in childcare and parenthood" (54). Elsewhere, in a discussion of how to help female farmers the report mentioned "working with male farmers so that they understand that supporting women's participation does not mean they are "mandarinas" (wimps/softies/unmanly) and training men to share domestic chores and childcare" (59 emphasis added). Another report recommended using the U.S. as a guide:

"one possible model is that of Family Resource Centers that have been established in poor latino communities in the United States to target mothers, fathers, adolescent boys, and adolescent girls in dealing with issues such as responsible fathering, male alcoholism, women's economic opportunities and empowerment, pregnancy among teenage girls, and gang violence and drug abuse among male adolescents. In particular, these centers have played an important role for men by broadening their roles as fathers" (Correia 2002: 206 emphasis added).

Although these policies to "broade(n) male gender roles" are understood to benefit all people (Correia 2000: xi), again certain men are targeted. These initiatives are explicitly 
intended to "promote men's roles as fathers and caregivers, particularly among unemployed men" (xi, emphasis added), because:

"Men are often underemployed or off work during economic downturns and therefore could share the burden of household responsibilities. In contrast, women often enter the workforce to compensate for household income losses during periods of economic crisis and have less time to engage in domestic chores" (xiv).

Here poor men appear excellent candidates for an easy resolution of tensions between unpaid care and renumerated labor that are of increasing concern to gender staff given the Bank's efforts to get women into employment (Bedford 2005a; b; 2006a; b). Indeed the Bank wants to know for sure how unemployed men are spending their time in order to know how to restructure it. A footnote to the discussion of promoting unemployed men's roles as fathers and caregivers proposed such a study, "with a view to learning if men are taking on new tasks in the household, if they are engaging in non- productive activities such as drinking" (Correia 2000: 44). Engagement with unpaid caring responsibilities thus becomes "productive" time use while consumption of purchased alcohol (which does, actually, generate growth) is non-productive. This claim simply makes no sense in a neoliberal economic model. It resonates instead on the Bank's complementary gender register in which poor men are visible as irresponsible drunks, targeted for inclusion in policy in order to ensure they love better when women move into work. The suggestion thus represents an interesting merging of the efficiency and complementarity constraints. The Bank wants quantified research on time use to ascertain productivity levels, but what counts as productive has been reconceptualized by pressures to include men and ensure gender policy produces "empowered" couples who privatize caring responsibilities.

\section{Directions for Future Analysis.}

To the extent that this exploration of Bank gender activities in Ecuador confirms what specialists already know about organizational liminality and efficiency constraints it 
provides further evidence of by-now standard conclusions about institutional influences on policy output. To the extent that it prompts new discussion about the complementarity constraint, however, it raises important questions regarding generalizability. The inherent limitations of one case study are compounded by specific concerns about the role of Moser in policy formation, the relative strength of gender policy entrepreneurs in this resident mission, the relative strength of their allies in the regional gender unit, and the generally favorable domestic environment in Ecuador since the mid 1990s, in which feminists have pushed through remarkable legislative and constitutional change (see footnote xvii). I thus do not situate the Ecuador case study as a "world in a teacup" (Geertz 1973: 23) representation of all Bank work on gender. Rather, I understand it as offering a close look at what happens when things go well. Precisely because feminists are relatively successful there, and precisely because Moser was so directly involved in research on gender policy, Ecuador can be assessed as a best case scenario outcome. Given that gender staff have been gaining space more broadly at the Bank since 1995, the findings here may be - or become of wider relevance.

On this tentative basis, then, the research suggests that the complementarity constraint needs to be taken far more seriously by feminist scholars, not least because it appears to lead to bad policy choices. Firstly it seeks to include men in extremely limited terms that pathologize already marginalized masculinities and that render individual poor men culpable for a range of development outcomes better explained - and resolved - at the suprahousehold level. Furthermore the example raises concerns that men are being included in gender lending to help reprivatize caring labor as women move into paid work. In utilizing the complementarity policy rationale, then, feminists are running the risk that their interventions are complicit in the neo-liberal retreat from social provisioning. 
Secondly, these policy solutions leave women utterly dependent on individuals who may, indeed, be lazy irresponsible drunkards. Those lacking access to, or opting to remain outside of, normative partnership models are made even more vulnerable to poverty, and many efforts to enhance women's autonomy by enabling them to break attachments to men are rendered unspeakable. Female-headed households, already framed in development discourse as disempowered despite their own protestations to the contrary (Chant 2006), are at particular risk here. With marriage affirmed as the ultimate anti-poverty strategy (Mink 1998), attention shifts from supporting women to keeping men around - whether or not their presence is considered empowering by the women involved, whether or not monogamous lifelong coupling is the predominant kinship pattern in the community in question, whether or not domestic feminists want to (or should) embrace a model of empowerment that requires people's necessary intimate attachment to predetermined others as a survival strategy.

Despite these serious limitations, however, little critical attention is paid to the complementarity constraint. The contrast with the treatment of the efficiency constraint is stark. When the Bank justifies its gender policies through references to productivity and growth, there is debate and dispute; there is currently no equivalent discussion when the Bank legitimizes interventions through references to empowering individuals by partnering them up with the "opposite" sex. This remains true even when, as in this example, the complementarity approach causes ugly fights with feminists unenthusiastic about holding poor men responsible for women's poverty, or celebrating human wholeness achieved through monogamous coupling. It is imperative that we ask ourselves why there is no equivalent debate.

I venture two suggestions in closing. Firstly, as noted in recent work on masculinity and development, there appears to be a reluctance to critically assess the troubling ways in which poor men have been framed in GAD policy (Jackson 2001; Cleaver 2002). Thus the 
Bank's targeting of poor men as violent, lazy, drunken problems suffering from wounded masculinity given their inability to live up to elite standards of manliness is allowed to pass without comment far too often. A simplistic, and offensive, model of gender oppression focusing on poor men's savagery is thus reinvigorated, while research on how non-elite men may forge counter-hegemonic masculinities with creative, productive potential (Connell 1995; Nguyen 2005) is ignored. In this respect critical scrutiny must be cast on dominant framings of poor masculinity if we want to in turn open up debate about the complementarity constraint.

Secondly, scrutiny must be given to the investments of development institutions in normative arrangements of intimacy. My research is not the first to make this point. Aside from contemporary work on the issue ${ }^{\mathrm{xxi}}$ it is worth recalling that early WID research offered a sharp critique of development institutions' attempts to produce the breadwinnerhousewife family (Rogers 1980; Kabeer 1994). Building on such work, it is necessary to explore how normative arrangements of intimate life are being shaped by social policy interventions, particularly those that naturalize certain forms of heterosexuality as universal and morally righteous (Berlant and Warner 1998, 548). Although these interventions have normally been explored on the state level, ${ }^{\text {xxii }}$ this research confirms that international policy agents like the Bank are also crucial actors in the production, reproduction, and alteration of forms of heterosexuality considered normative. However they are rarely examined as such, in part because the arrangements of intimacy being promoted are so successfully naturalized. Monogamous lifelong coupling has become Wolfowitz's two-wheeled cart such an obvious, common-sense component of normalcy that movement can not even be imagined without it. Until such representations are challenged, and analyzed as products of institutional constraints, gender scholars can make little progress in reformulating the Bank's approach. 
This is not to suggest that development femocrats can - or should - simply eschew a complementary policy rationale. The issue clearly requires more research, analysis, and dialogue, and sharing models may contain radical potential. Moreover, to draw a simplistic comparison, efficiency constraints are hotly debated but they have to be used to get mainstream support; discourses of balanced sharing are, in the short term at least, likely to be equivalent. I instead imagine a scenario in which complementarity discourses are seen as strategic tools, employed reluctantly when necessary and open for contestation and debate; in which policy entrepreneurs try to advance an avidly pluralistic approach to kinship and family formation emphasizing the vast number of ways in which happy, functional, empowered people arrange their intimate lives; in which feminists debate a range of solutions to the dilemma between paid and unpaid work and address the danger that we are complicit in reprivatizing caring labor; a scenario, in short, in which complementarity constraints are regarded as constraints, with potentially negative effects. Such progress will not only facilitate more accurate understanding of the policies forged in the world's largest development institution; it will also facilitate their contestation.

\section{Conclusion.}

The Bank's shifting mission requires that scholars consider the emergence of new institutional constraints on policy entrepreneurs who are attempting to reform the organization's development approach, while remaining attentive to the "stickiness" of efficiency rationales therein. In this spirit, my research confirms the continued frustrations encountered by feminist insider-outsiders who are pressured to make their policy interventions look productive, while also drawing attention to the pressure to include men in gender lending. In Ecuador, this constraint had concrete - and negative - consequences for the policies forged by staff. Not only were domestic allies confused and sometimes 
angered by the need to focus on complementary sharing, but men were hailed for inclusion in troubling ways. Specifically, the institutional pressure to define successful gender policy through a complementary focus on couples led poor men to become hyper-visible as irresponsible partners, and as the crux of the gender policy problem. In turn Bank gender policy was focused on efforts to change them, by encouraging their responsible attachment to family and willingness to do domestic labor.

While reluctant to generalize worldwide from this case study, I suggest that these findings may have broader reach given Ecuador's importance as a site for relatively successful gender policy entrepreneurship in the Bank. Staff experiences here may have considerable import, providing a set of likely directions for future interventions elsewhere. This is, frankly, an unsettling conclusion, one suggesting the need for further case studies, comparative work, and institutional ethnography. Furthermore, the findings highlight the importance of placing feminist development research in conversation with other literatures, particularly from masculinity and sexuality studies. Although such connections remain unusual, pursuing them may greatly aid feminists us we consider how best to navigate organizational agendas to enact transformative policy. 
Acknowledgements

Research for this project was partially enabled by a grant from the PORT fund, Department of Political Science, Rutgers University. World Bank staff and consultants in Ecuador were very generous with their time. The author also thanks Leela Fernandes, Mary

Hawkesworth, Davina Cooper, Amy Lind, Suzanne Bergeron, Drucilla Barker, Anna Marie Smith, Cathy Cohen, Ara Wilson, and participants in the Barnard Center for Research on Women lunchtime seminar for comments on previous drafts of this argument. 


\section{Works Cited.}

Adams, V. and Pigg, S. L. (eds.). 2005. Sex in Development: Science, Sexuality, and Morality in Global Perspective. Durham: Duke University Press.

Alexander, M. J. 1994. 'Not Just (Any) Body Can Be a Citizen: The Politics of Law, Sexuality and Postcoloniality in Trinidad and Tobago and the Bahamas', Feminist Review 48: 5-23.

Baden, S. and Goetz, A.M. 1997. 'Who needs (sex) when you have (gender)? Conflicting Discourses on Gender at Beijing', in Staudt, K. (ed.) Women, International Development, and Politics: The Bureaucratic Mire, revised edition. Philadelphia: Temple University Press.

Bedford, K. 2005a. 'Empowering Women, Domesticating Men, and Resolving the Social Reproduction Dilemma: The World Bank's Employment Policies in Ecuador and Beyond'. PhD Dissertation, Department of Political Science, Rutgers University.

-----. 2005b. 'Loving to Straighten Out Development: Sexuality and 'Ethnodevelopment' in the World Bank's Ecuadorian Lending', Feminist Legal Studies 13: 295-322.

-----. 2006a. Governing Intimacy in the World Bank. In Rai, S. and Waylen, G. (eds.) Analyzing and Transforming Global Governance: Feminist Perspectives. Cambridge: Cambridge University Press.

Bergeron, S. 2004. Fragments of Development: Nation, Gender, and the Space of Modernity. Ann Arbor: University of Michigan Press.

Berlant, L. and Warner, M.1998. 'Sex in Public,' Critical Inquiry: 547-66.

Birdsall, N. and Kapur, D. 2005. The Hardest Job in the World: Five Crucial Tasks for the New President of the World Bank. Washington D.C.: Center for Global Development.

Bloch, F. and Rao, V. 2000. Terror as a Bargaining Instrument: A Case Study of Dowry Violence in Rural India. Policy Research Working Papers 2347. Washington D.C.: World Bank.

Buvinic, M., Gwin C., and Bates, L. 1996. Investing in Women: Progress and Prospects for the World Bank. Washington, D.C.: Overseas Development Council/International Center for Research on Women.

Calderisi, R. 2006. 'The Worst Man in the World?', New Statesman, 15 May' 22-25.

Caufield, C. 1996. Masters of Illusion: The World Bank and the Poverty of Nations. New York: Henry Holt \& Co.

Chant, S. 2006. 'Contributions of a Gender Perspective to the Analysis of Poverty', in Jaquette, J. and Summerfield, G. (eds.) Women and Gender Equity in Development 
Theory and Practice: Institutions, Resources, and Mobilization. Durham: Duke University Press.

Cleaver, F. (ed). 2002. Men and Masculinities: New Directions in Gender and Development. New York: Zed Books.

Cohen, C. 1997. 'Punks, Bulldaggers, and Welfare Queens,' GLQ 3: 437-65.

Connell, R.W. 1995. Masculinities. Berkeley: University of California Press.

Cooper, D. 1995. Power in Struggle: Feminism, Sexuality and the State. Buckingham: Open University Press.

Correia, M. 2000. Ecuador Gender Review: Issues and Recommendations. A World Bank Country Study. Washington D.C.: World Bank.

------. 2002. 'Gender Dimensions of Vulnerability to Exogenous Shocks: The Case of Ecuador,' in P. Beckerman and A. Solimano (eds), Crisis and Dollarization in Ecuador: Stability, Growth, and Social Equity pp: 177-215. Washington D.C.: World Bank.

Danaher, K. (ed.). 1994. Fifty Years Is Enough: The Case against the World Bank and the International Monetary Fund. Boston: South End Press.

Escobar, A.1995. Encountering Development: The Making and Unmaking of the Third World. Princeton: Princeton University Press.

- 1997. 'Anthropology and Development', International Social Science Journal 49.4: 497-516.

Ferree Marx, M. and Yancey Martin, P. 1995. 'Doing the Work of the Movement: Feminist Organizations,' in Feminist Organizations: Harvest of the New Women's Movement, pp: 3-23. Philadelphia: Temple University Press.

Fretes-Cibils, V., Giugale, M. and López-Cálix, J. (eds.) 2003. Ecuador: An Economic and Social Agenda in the New Millennium. Washington D.C.: World Bank.

Fox, J. and Brown, D. (eds.). 1998. The Struggle for Accountability: The World Bank, NGOs, and Grassroots Movements. Cambridge: MIT Press.

Geertz, C. 1973. The Interpretation of Cultures: Selected Essays. New York: Basic Books.

George, S. and Sabelli, F. 1994. Faith and Credit: The World Bank's Secular Empire. Boston: Westview Press.

Gilbert, C. and Vines, D. (eds.) The World Bank: Structure and Policies. New York: Cambridge University Press.

Goldman, M. 2005. Imperial Nature: The World Bank and Struggles for Social Justice in the Age of Globalization. New Haven: Yale University Press. 
Goetz, A. M. 1997. Getting Institutions Right for Women in Development. New York: Zed Books.

Gutmann, M. (ed.). 2003. Changing Men and Masculinities in Latin America. Durham: Duke University Press.

Hafner-Burton, E. and Pollack, M. 2002. 'Mainstreaming Gender in Global Governance,' European Journal of International Relations 8 (3): 339-73.

Herrera Mosquera, G. (ed.). 2001. Antología De Estudios De Género. Quito: FLASC0Ecuador/ILDIS.

Hoad, N. 2000. 'Arrested Development or the Queerness of Savages: Resisting Evolutionary Narratives of Difference', Postcolonial Studies 3 (2):133-158.

Jackson, C. (ed). 2001. "Men at Work” Men and Work: Labour, Masculinities, Development. Portland: Frank Cass.

Jaquette, J., and Summerfield, G. (eds.). 2006. Women and Gender Equity in Development Theory and Practice: Institutions, Resources, and Mobilization. Durham: Duke University Press.

Kabeer, N. 1994. Reversed Realities: Gender Hierarchies in Development Thought. New York: Verso.

Kabeer, N., and R. Subrahmanian (eds.). 2000. Institutions, Relations, and Outcomes: Frameworks and Case Studies for Gender-Aware Planning. London: Zed Books.

Katzenstein, M. F. 1998. Faithful and Fearless: Moving Feminist Protest Inside the Church and Military. Princeton: Princeton University Press.

Kuiper, E. and Barker, D. 2006. Feminist Economics and the World Bank: History, Theory and Policy. New York: Routledge.

Long, C. 2003. The Advocate's Guide to Promoting Gender Equality at the World Bank. Washington D.C.: Women's Edge.

Lind, A. 2005. Gendered Paradoxes: Women's Movements, State Restructuring, and Global Development in Ecuador. University Park: Pennsylvania State University Press.

Mallaby, S. 2004. The World's Banker: A Story of Failed States, Financial Crises, and the Wealth and Poverty of Nations. New York: Penguin Press.

Melhaus, M. and Stolen K. A. (eds). 1996. Machos, Mistresses, Madonnas: Contesting the Power of Latin American Gender Imagery. London: Verso. 
Miller, C. and Razavi. S. 1998. 'Introduction,' in Missionaries and Mandarins: Feminist Engagement with Development Institutions. London: Intermediate Technology Publications/United Nations Research Institute for Social Development.

Mink, G. 1998. Welfare’s End. Ithaca: Cornell University Press.

Moser, C. 1993. Gender Planning and Development: Theory, Practice and Training. New York: Routledge.

1996. Confronting Crisis: A Summary of Household Responses to Poverty and Vulnerability in Four Poor Urban Communities. Environmentally Sustainable Development Studies and Monographs Series No. 7. Washington D.C.: World Bank.

1997. Household Responses to Poverty and Vulnerability Volume 1: Confronting Crisis in Cisne Dos, Guayaquil, Ecuador. Urban Management Program Policy Paper 21. Washington D.C..: World Bank.

Moser, C., Törnqvist, A., and von Bronkhorst, B. 1999. Mainstreaming Gender and Development in the World Bank: Progress and Recommendations. Washington D.C.: World Bank.

Murphy, J. 1995. Gender Issues in World Bank Lending. Washington D.C.: World Bank.

Narayan, D. et al. 2000. Can Anyone Hear Us? Voices of the Poor Series. New York: Oxford University Press.

Newman, C. 2001. Gender, Time Use, and Change: Impacts of Agricultural Export Employment in Ecuador. Washington, D.C.: World Bank.

Nguyen, V-K. 2005. 'Uses and Pleasures: Sexual Modernity, HIV/AIDS, and Confessional Technologies in a West African Metropolis', in Adams, V. and Pigg, S. L. (eds.) Sex in Development: Science, Sexuality, and Morality in Global Perspective, pp. 245-267. Durham: Duke University Press.

North, L. 2004. 'State Building, State Dismantling, and Financial Crises in Ecuador', in J. Burt and P. Mauceri (eds.) Politics in the Andes: Identity, Conflict, Reform, pp. 186206. Pittsburgh: University of Pittsburgh Press.

Norton, N. and Morris, B. 2003. 'Feminist Organizational Structure in the White House: The Office of Women's Initiatives and Outreach', Political Research Quarterly 56 (4): $477-487$

O'Brien, R. et al. 2000. Contesting Global Governance: Multilateral Economic Institutions and Global Social Movements. Cambridge: Cambridge University Press.

Parpart, J. 2002. 'Lessons from the Field: Rethinking Empowerment, Gender and Development from a (Post-) (Post?) Development Perspective', in Saunders, K. (ed.) Feminist Post-Development Thought: Rethinking Modernity, Post-Colonialism and Representation, pp: 41-56. New York: Zed Books. 
Pincus, J. R. and Winters, J. 2002. 'Reinventing the World Bank', in Reinventing the World Bank pp: 1-25. Ithaca: Cornell University Press.

Prieto, M. (ed.). 2005. Mujeres Ecuatorianas: Entre las crisis y las oportunidades 19902004. Quito: CONAMU.

Rathgeber, E. 1995. 'Gender and Development in Action,' in Marchand, M. and Parpart, J. (eds) Feminism/Postmodernism/Development. New York: Routledge.

Reddy, S. and Pogge, T. 2005. How Not To Count the Poor. Available online at www.socialanalysis.org (accessed October 15 2005).

Rogers, B. 1980. The Domestication of Women: Discrimination in Developing Societies. London: Kogan Page.

Rothschild, C. 2000. Written Out: How Sexuality is Used to Attack Women's Organizing. IGLHRC/CWGL. Available on-line at: http://www.iglhrc.org/publications/books/WrittenOut/index.html (accessed 13 March 2002).

Saunders, K. (ed). 2002. Feminist Post-Development Thought: Rethinking Modernity, PostColonialism and Representation. New York: Zed Books.

Sen, G. and C. Grown. 1985. Development, Crises and Alternative Visions: Third World Women's Perspectives. Bangalore: DAWN Secretariat.

Staudt, K. 2002. 'Dismantling the Master's House with the Master's Tools? Gender Work in and with Powerful Bureaucracies', in Saunders, K. (ed.) Feminist PostDevelopment Thought: Rethinking Modernity, Post-Colonialism and Representation, pp: 57-68. New York: Zed Books.

Törnqvist, A. 2004. 'Mainstreaming Gender in Indigenous Projects and Projects Affecting Indigenous peoples in the World Bank Portfolio: The PROGENIAL Experience', in S. Davis, S., Uquillas, J., and Eltz, M. (eds.), Lessons of Indigenous Development in Latin America: The Proceedings of a World Bank Workshop on Indigenous Peoples Development, pp:95-90. LCR Sustainable Development Working Paper 20. Washington D.C.: World Bank.

UN ESOSOC. 1997. Agreed Conclusions on Gender Mainstreaming. Geneva: United Nations Economic and Social Council. Available on-line http://www.un.org/documents/ecosoc/docs/1997/e1997-66.htm. (accessed 16 May 2006).

Waylen, G. 2004. 'Putting Global Governance into the Gendered Political Economy of Globalization,' International Feminist Journal of Politics 6 (4): 557-578.

Weldon, S. L. 2002. Protest, Policy, and the Problem of Violence Against Women: A Cross National Comparison. Pittsburgh: University of Pittsburgh Press. 
Whitten, N. (ed.). 2003. Millennial Ecuador: Critical Essays on Cultural Transformations and Social Dynamics. Iowa City: University of Iowa Press.

Wolfensohn, J. 1995. Women and the Transformation of the Twenty First Century. Address to the Fourth UN Conference on Women, Beijing (September 15): World Bank.

Wolfowtiz, Paul. 2006. Opening Remarks at High-Level Consultation: Promoting the Gender Equality MDG: The Implementation Challenge. Available at www.worldbank.org/gender/ (accessed 15 April 2006).

Wood, C. A. 2003. 'Adjustment with a Woman's Face: Gender and Macroeconomic Policy at the World Bank,' in Eckstein, S. E. and Wickham-Crowley, T. (eds.) Struggles for Social Rights in Latin America pp:209-30. New York: Routledge.

World Bank. 1994. Enhancing Women's Participation in Economic Development: A World Bank Policy Paper. Washington D.C.: World Bank.

1995a. Advancing Gender Equality: From Concept to Action. Washington D.C.: World Bank.

1995b. Beyond Beijing: Promoting Gender Equality: Our Shareholders Views. Washington D.C.: World Bank.

1995c. Toward Gender Equality: The Role of Public Policy, Development in Practice. Washington D.C.: World Bank.

. 1996. Ecuador Poverty Report: A World Bank Country Study. Washington D.C.: World Bank.

1997. Implementing the World Bank's Gender Policies: Progress Report 2.

Washington D.C.: World Bank.

. 2000a. Advancing Gender Equality: World Bank Action since Beijing. Washington

D.C.: World Bank.

. 2000b. Précis: Evaluating Gender and Development at the World Bank.

Operations Evaluation Department. Washington D.C. World Bank.

- 2001. Engendering Development through Gender Equality in Rights, Resources, and Voice Washington D.C.: World Bank/Oxford University Press.

-----. 2006. World Development Report: Equity and Development. Washington D.C.:

World Bank.

Zuckerman, E. and Qing, W. 2003. Reforming the World Bank: Will the New Gender Strategy Make a Difference? A Study With China Case Examples. Washington D.C: Heinrich Boll Foundation/Gender Action. 


\footnotetext{
${ }^{\mathrm{i}}$ E.g. Norton and Morris 2003; Katzenstein 1998; Ferree and Martin 1995, Weldon 2002.

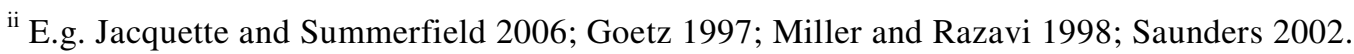

${ }^{\text {iii }}$ Staudt 2002; Kabeer and Subrahmanian 2000; Hafner-Burton and Pollack 2002; Waylen 2004.

iv The "World Bank" refers to the two most prominent agencies in the World Bank Group: the International Bank for Reconstruction and Development and the International Development Association. 'This is not, of course, to suggest that the Bank's expert status is uncontested; in contrast Wolfensohn's attempts to market the institution as the world's "Knowledge Bank on development" have been challenged by several scholars. See, for example, Bergeron 2004, 113-4, Goldman 2005; Reddy and Pogge 2003.

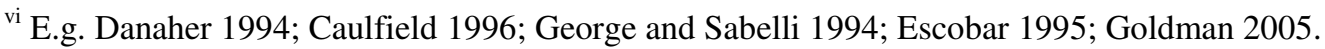
vii http://web.worldbank.org/WBSITE/EXTERNAL/EXTABOUTUS/ORGANIZATION/PRESIDENTEXT ERNAL/0,,contentMDK:20083965 menuPK:232070 pagePK:139877 piPK:199692 theSitePK:227585,
} 00.html. Accessed March 2005.

viii Joseph Stiglitz (hired as the Bank's chief economist by Wolfensohn) resigned after his public criticism of neo-liberalism and the IMF, and Ravi Kapur (chief architect of the Bank's 2000-1 World Development Report on empowerment and participation) left after Bank authorities insisted the report get toned down (Parpart 2002; Mallaby 2004).

${ }^{\text {ix }}$ When asked to register their reaction to his appointment in June 20051300 Bank staff responded within two days, 92\% expressing disapproval (Calderisi 2006, 23).

${ }^{\mathrm{x}}$ When the Bank first included WID in its 1975 annual meeting the event was included on the spouses program (Murphy 1995, 32); this happened again in 1980 (33).

${ }^{\mathrm{xi}}$ For example authors of several Bank gender documents have consulted with NGOs and feminist political economists prior to the publication of their research (e.g. World Bank 1995c, ix; World Bank 2001, xviii).

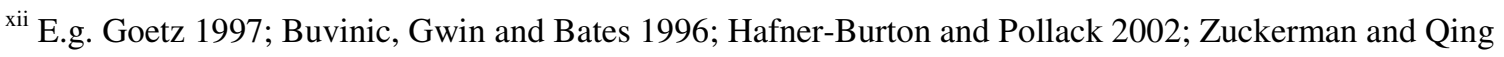
2003.

xiii For example Baden and Goetz note that evidence on the correlation between education and fertility decline is "tenuous" (1997, 43), yet it remains central to much Bank gender policy.

${ }^{\text {xiv }}$ See for example the Bank's Voices of the Poor study (Narayan et al 2000). 
${ }^{\mathrm{xv}}$ I explore them in greater depth in Bedford 2005a. In particular, space prohibits examination of the links between Bank gender efforts and U.S. attempts to strengthen families and alleviate poverty through marriage.

xvi

http://wbln0018.worldbank.org/LAC/LAC.nsf/ECADocByLink/6C41D4D2AA155AE485256C60005EE134?

OpenDocument. Accessed 5 September 2006.

xvii Images of balanced couples are ubiquitous signifiers of the Bank's successful gender interventions (Bedford 2005a); I have a collection available on request.

${ }^{\text {xviii }}$ See Lind 2005; Herrera 2001; Prieto 2005 for an introduction to the Ecuadorian women's movement.

${ }^{\text {xix }}$ See Rothschild 2000 for more on lesbian-baiting as a way to counter women's international organizing.

${ }^{x x}$ I note this not to denigrate the conference paper, but to highlight the politics of citation evident in the Bank's referencing practices, whereby some work on masculinity is visible because it makes particular men visible in particular ways. See Bedford 2006a.

${ }^{x x i}$ E.g. Chant 2006, Adams and Pigg 2005, Alexander 1994; Hoad 2000

xxii E.g. Cohen 1997; Cooper 1995. 